\title{
Emlékezés Szathmári Istvánra
}

Szathmári tanár úrtól, akivel sok évig együtt dolgozhattam az ELTE Mai Magyar Nyelvi Tanszékén és a Stíluskutató csoportban, tanítványaként búcsúzom, csatlakozva az előttem szólókhoz.

Szathmári István a magyar nyelvtudomány nagy generációjának egyik utolsó képviselöje volt. A nyelvtudomány több területén is kiemelkedőt alkotott. Kutatásai fontos eredményeket hoztak többek között a stilisztika, a nyelvtörténet és a nyelvjárástan területén is. Az irodalmi nyelv történetével kapcsolatos kutatásai ugyanúgy nagy jelentőségüek, mint a nyelvtudomány történetével kapcsolatos vizsgálódásai. Ahogy ő maga használta ezt a kifejezést: igazi filológus volt. A nyelvi jelenségekhez elsősorban azok történetisége felől közelített. Ennek keretében egyfelől feladatának tekintette a nyelvi adatok alapos, részletes elemzését, másfelől nem tévesztette szem elől a vizsgált nyelvi jelenségek tágabb, nevezzük így: müvelődéstörténeti kontextusát sem. Kutatásait így egyszerre jellemezte az elmélyültség és a távlatosság. Szathmári István rendkívül gazdag és izgalmas életmüvet hagyott maga után. Kutatásainak eredményei jelen vannak, azok további kutatásokra ösztönzik az utána jövőket.

A gazdag és izgalmas életmünek, illetve életnek én most csak egy szeletére, igaz, kulcsfontosságú szeletére szeretnék vázlatosan utalni. E helyütt, néhány szó erejéig elsősorban a magyar stilisztika korszakos alakja előtt szeretnék tisztelegni. Szathmári István stilisztikai tárgyú munkái máig meghatározzák a nyelvi stílusról való gondolkodást. Egyike volt azoknak, akik megalapozták Magyarországon a modern stilisztikát, határozott nyelvészeti karaktert adva az ilyen irányú kutatásoknak. Egyfelől társszerzője volt A magyar stilisztika vázlata címü kézikönyvnek (FÁBIÁN-SZATHMÁRI-TERESTYÉNI 1958), másfelől ő jegyzi A magyar stilisztika útja címü nagyívü áttekintést (SZATHMÁRI 1961). E ma már klasszikusnak számító kötetek - az évek során kiegészülve további kötetekkel (1. pl. SZATHMÁRI 1994, 2005) - a magyar stilisztika történetének fontos szövegei, amelyek a modern stilisztikai kutatások megalapozását két irányból végzik el. Egyfelől számot vetnek a tágan értett strukturalista nyelvtudománynak azokkal az eredményeivel, amely a stílus szisztematikus nyelvészeti leírásának adnak keretet. E tekintetben elsősorban a Saussure-tanítvány Charles Ballynak és követőinek a stilisztikai munkái hatottak a leginkább a Szathmári István által kidolgozott stílusmagyarázatra (1. erről pl. SZATHMÁRI 2004, SZATHMÁRI szerk. 1996). Másfelől feldolgozzák a hazai stílussal való foglalkozás történetét, és így a modern stilisztikai kutatásokat a korábbi, huszadik század előtti kutatások szerves folytatásaként is fel tudják mutatni.

A magyar stilisztikai kutatások története szempontjából ugyancsak nagy a jelentősége annak, hogy Szathmári István 1970-ben megalapította, és 2008-ig vezette az azóta is folyamatosan müködő Stíluskutató csoportot. A Stíluskutató

Magyar Nyelv 117. 2021: 7-9. DOI: https://doi.org/10.18349/MagyarNyelv.2021.1.7 
csoport a kezdetektől az ELTE Mai Magyar Nyelvi Tanszéke mellett müködött, de munkájába más intézmények stilisztikával foglalkozó kutatói is bekapcsolódtak, és a nyolcvanas évekre szinte már az összes magyarországi felsőoktatási intézményből voltak tagjai a csoportnak. A Szathmári István köré szerveződő kutatócsoport kiemelten foglalkozott a stílustörténet problematikájával, azon belül is a századforduló stílustörekvéseivel (l. FÁBIÁN-SZATHMÁRI szerk. 1989), majd a kilencvenes években izgalmas diskurzust kezdeményezett a stíluselmélet időszerü kérdéseiről (1. SZATHMÁRI szerk. 1996), illetve az elméleti belátások alkalmazhatóságáról (1. SZATHMÁRI szerk. 1998). A kétezres években Szathmári István a csoport érdeklődésének fókuszába az alakzatkutatást helyezte. Az alapozó jellegü munkálatok után (1. ehhez SzATHMÁRI szerk. 2003, 2006) a csoport elkészítette a retorikai háttérnek is kellő figyelmet szentelő, de elsősorban az alakzatok stilisztikai funkciójára összpontosító, hiánypótlónak tekinthető Alakzatlexikont (SZATHMÁRI föszerk. 2008).

Ebben az utóbbi tudományos vállalkozásban magam is részt vettem. Így fiatal kutatóként közvetlenül megtapasztalhattam, hogyan kell irányítani kellő tapintattal, ugyanakkor kellő határozottsággal egy nagy létszámú és sokszínű kutatócsoportot, hogyan kell élénk szakmai vitákat kezdeményezni és azokat mederben tartani, azaz hogyan kell egy kutatócsoport munkáját összehangolni és azt eredményessé tenni. Lehet, hogy mindez másnak is sikerült már, illetve másnak is sikerülhet még. Ám sokan tanúsíthatjuk, hogy olyan módon, ahogyan ezt Szathmári tanár úr tette, már nem megismételhető. A Stíluskutató csoport müködése azonban nem ért teljes meglepetésként, hiszen a csoport munkájába Szathmári tanár úr doktoranduszaként, az ő hívására kapcsolódtam be. A doktori képzés alatt megtapasztalt közvetlensége, derüs humora, barátságos jóindulata tekintélyt parancsoló volt. Szigorát természetesnek vettük, mert egyénített figyelmet és iránymutatást, személyre szabott feladatokat és értékeléseket, személyre szabott kérdéseket és válaszokat kaptunk tőle. Sokszor és sokan elmondták, de most is el kell mondani: igazi tanáregyéniség volt, tanítványainak nemcsak a tudományos, hanem a tanári pályáját is figyelemmel kísérte, támogatta.

Akik együtt dolgozhattunk vele, akik ismerhettük öt, embersége által is többek lettük. A tudománnyal való foglalkozás szüneteiben az is kiderült, hogy nagyon jó mesélő. Történetei - a gyerekkoráról, a szülőföldjéről, a debreceni, a szegedi és a pesti évekről, mestereiről, pályatársairól, önmagáról - nemcsak érdekesek és tanulságosak voltak: mindig tele voltak élettel. Távozásával Szathmári tanár úr nem pótolható ürt hagyott maga után, de életmüve, embersége továbbra is velünk marad. Emlékét megőrizzük.

\section{Hivatkozott irodalom}

FÁBIÁN PÁL - SZATHMÁRI ISTVÁN - TERESTYÉNI FERENC1958. A magyar stilisztika vázlata. Tankönyvkiadó, Budapest.

FÁBIÁN PÁL - SZATHMÁRI ISTVÁN szerk. 1989. Tanulmányok a századforduló stílustörekvéseiröl. Tankönyvkiadó, Budapest. 
SZATHMÁRi IstVÁn 1961. A magyar stilisztika útja. Akadémiai Kiadó, Budapest.

SZATHMÁRI ISTVÁN 1994. Stílusról, stilisztikáról napjainkban. Nemzeti Tankönyvkiadó, Budapest.

SZATHMÁRI ISTVÁN 2004. A funkcionális stilisztikáról. Magyar Nyelvőr 128: 435-440.

SZATHMÁRI ISTVÁN 2005. A magyar stilisztika a kezdetektöl a XX. század végéig. Tinta Könyvkiadó, Budapest.

SZATHMÁRI ISTVÁN szerk. 1996. Hol tart ma a stilisztika? Stíluselméleti tanulmányok. Nemzeti Tankönyvkiadó, Budapest.

SzATHMÁRI ISTVÁN szerk. 1998. Stilisztika és gyakorlat. Nemzeti Tankönyvkiadó, Budapest.

SZATHMÁRI ISTVÁN szerk. 2003. A retorikai-stilisztikai alakzatok világa. Tinta Könyvkiadó, Budapest.

SZATHMÁRI ISTVÁN szerk. 2006. A stilisztikai alakzatok rendszerezése. Tinta Könyvkiadó, Budapest.

SZATHMÁRI ISTVÁN föszerk. 2008. Alakzatlexikon. A retorikai és stilisztikai alakzatok kézikönyve. Tinta Könyvkiadó, Budapest.

TÁTRAI SZILÁRD

ELTE Eötvös Loránd Tudományegyetem 